\title{
ANALYSIS OF CONSTRUCTION SALT DECOMPOSITION WITHIN WALLS OF CERAMIC BRICK IN THE MIDTOWN TENEMENT HOUSES
}

\author{
Bartosz SZOSTAK ${ }^{1}$, Maciej TROCHONOWICZ ${ }^{2}$ \\ Lublin University of Technology \\ Department of Construction and Architecture, Lublin, Poland
}

\begin{abstract}
The purpose of this paper is to introduce issues related to the corrosive effects of construction salts. Sequentially, one will discuss issues related to the distribution of salt in the wall, salinity sources and types of masonry material damage. There will also be presented the results of research conducted by the authors, which allowed determining the distribution of salinity in the walls depending on the depth and height of sampling. The paper will present test results of samples taken from several heights and depths within the same piece of wall and summaries from all facilities. Research conducted by the authors were based on chemical analyzes performed using the prepared chemical tests. Assays are made using titration and colorimetric methods.
\end{abstract}

Keywords: water-soluble salts, walls of ceramic brick

\section{INTRODUCTION}

Water-soluble salts, described as the construction salts, belong to the most dangerous factors degrading the construction objects. The phenomenon of salt crystallization causes serious damage within the basement of the building. This problem is particularly important in the case of old walls, without insulation, of historical and historic downtown buildings.

\footnotetext{
${ }^{1}$ Corresponding author: Lublin University of Technology, Department of Construction and Architecture, Nadbystrzycka st 38 D, 20-618 Lublin, Poland, e-mail: b.szostak@pollub.pl, tel.+48815384412

2 m.trochonowicz@pollub.pl, tel.+48815384412
} 
The purpose of this paper is to introduce issues related to the corrosive effects of construction salts. Sequentially, one will discuss issues related to the distribution of salt in the wall, salinity sources and types of masonry material damage. There will also be presented the results of research conducted by the authors, which allowed determining the distribution of salinity in the walls depending on the depth and height of sampling.

\section{SALTS OF CONSTRUCTION}

From the chemical point of view, salts are the substances resulting from the neutralization reaction of acid with a base. The reaction of salt depends on what substances were involved in the process of its creation. In the case of the strong acid and base and the weak acid and base, it will be almost neutral. Salts may also have acidic reactions with a strong acid and weak base and to be alkaline and in a reverse system. It should be remembered that these compounds may then react with building materials such as acids and bases. From the building point of view the most important are the salts easily soluble in water, and hence those in which it is relatively easily to break apart into ions. The chemical composition of salt is a factor accounting for the degree of hazard. It has a direct impact, scope and intensity of destructive processes associated with the presence of these compounds in the material.

The most common salts soluble in the water present in the construction works are sulphates, nitrates, chlorides, and carbonates. The most common sulphates in construction include sodium sulphate anhydrous and hydrated, potassium sulphate, calcium sulphate dehydrate, and magnesium sulphate. Nitrates are salts of nitric acid. In construction, there are nitrates of: sodium (nitrate of soda), potassium (potassium nitrate), ammonium (ammonium nitrate), calcium, and magnesium. Most of the chloride salts are readily soluble in water. In materials and building partitions, one can meet sodium chloride, potassium chloride, ammonium (ammonium chloride), calcium chloride and magnesium chloride. The best-known inorganic chloride salt is sodium chloride. Carbonates are the salts and esters of carbonic acid. The most common carbonates are calcium carbonate, hydrated sodium carbonate, sodium carbonate and ammonium carbonate[0][5][3].

\subsection{The sources of salinity}

Excessive salinity is a main problem of old buildings that do not have insulation or existing insulations are inoperable. Such buildings are exposed to constant contact with moisture. Water, contaminated with salt ions, enters the partitions, 
then it is transported therein, and after the evaporation crystallization occurs. The most important sources of salinity can include salts:

- included and washed out of the building materials,

- pulled in dissolved form from the ground,

- used for winter maintenance of streets and sidewalks

- hitting with precipitation,

- derived from leaking sewage,

- introduced during maintenance and impregnation [4].

Raw materials, which building materials are manufactured from, contain certain quantities of soluble salts. Additionally, in the preparation of the materials and their incorporation, there can be built another compounds. Fairly high concentrations of building salts are present in bonds of: cement, plaster and lime, but also in masonry materials: bricks and hollow blocks. In the case of old buildings, large amounts of salt get into the walls with damp rising from the ground. This applies mainly to all nitrates and chlorides. In connection with the above, there were pits, within old buildings, with impurities, buildings with the inventory, in the ground there are large amounts of nitrates and nitrites. The presence of chlorides is primarily a result of the use of salt in the winter. The main salt source from the group of sulphates is materials reactions with polluted air. Installation failures of sanitary sewage systems, apart from flooding, also cause local salting out. The range of defects is then related to the places of failure. The sources of salinity are also biocides and wood preservatives used in the facility and mismatched methods and means used in restoration works.

\subsection{Distribution in partition wall and corrosive effect of salt}

The mechanism of the corrosive action of the salt is based on the physical and chemical processes and substance conditioning the processes of destruction is water. The salts as solids do not move automatically in the materials. Therefore, in the corrosion processes, those have the part that very well and well dissolve in water. In the form of solution, they reach places where the water is transported. Accumulation of them occurs in a place where water evaporates, there they also crystallize. The phenomenon of salt movement is called "migration to the surface".

The destructive effects of salt are based on a phenomenon associated with crystallization and enlarging their volume. The resulting pressure is high and sufficient to cause a crack of the pore walls in the material, loosening surface layers and consequently leading to the granular disintegration, decortications, cracking and disintegration. For a large group of salt, this pressure is greater than $100 \mathrm{MPa}$ and can reach up to 240 . 
Salts after the crystallization process in the wall pores and capillaries, or on the surface of the element still remain readily soluble. After delivery of the required amount of moisture, they pass into solution and, on changing the conditions, crystallize again, causing more destruction.

Some of the salt has a hygroscopic property, so that dissolution does not need water in liquid form. Sufficient quantities are retrieved from the humid air. The result of such a process is a local dampness, visible on the walls and plaster works, in the form of dark and damp stains.

Another quality disadvantage of the construction salt is the possibility of their hydration, resulting in the growth of existing crystals. Hydration pressure is so high that it causes similar effects to crystallization.

The destructive effects of salt can have multiple effects. For continuous transport of the salt solution, the crystallization occurs on the surface of the element. We can then talk about the less immediate threat of destruction, but a significant deterioration of the material surface aesthetics. The salts on the surface of the material can be crystallized in the form of spots, damp patches, efflorescence, fluffy tarnish and vitreous coatings. This form depends on the type and amount of salt, and also on the conditions under which crystallization occurs.

Where the feed rate of the solution is smaller, there is a process of moisture evaporation the interior of the wall and crystallization within the subsurface layers. Such a course of events causes much more serious corrosion of the walls. Up to a certain point, there are no visible effects of degradation, then the whole plaster passages or masonry exterior surface are damaged.

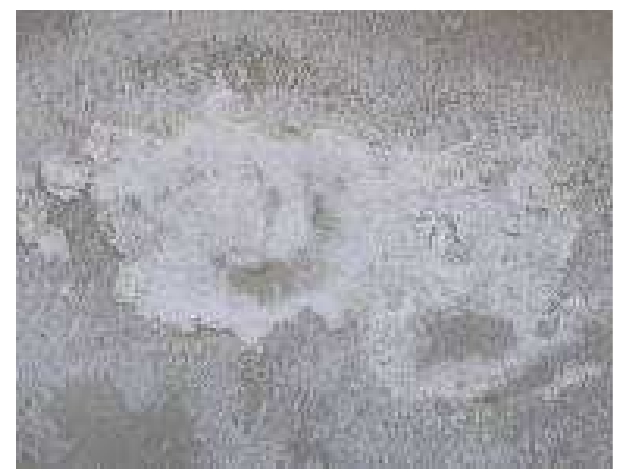

Fig. 1. Surface crystallization-wall and plaster remain overdamped

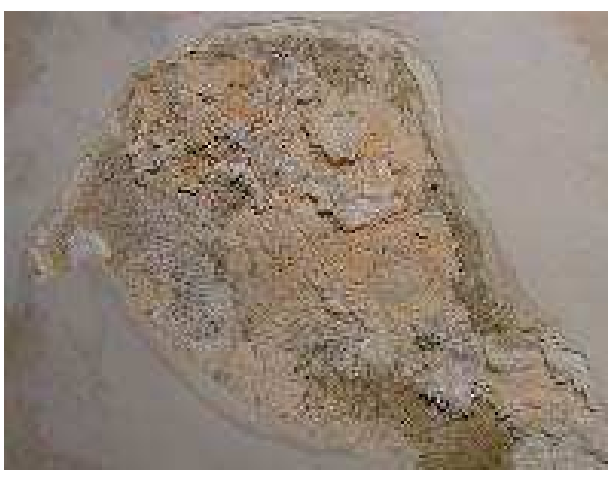

Fig. 2. Crystallization of the salt within the plaster 


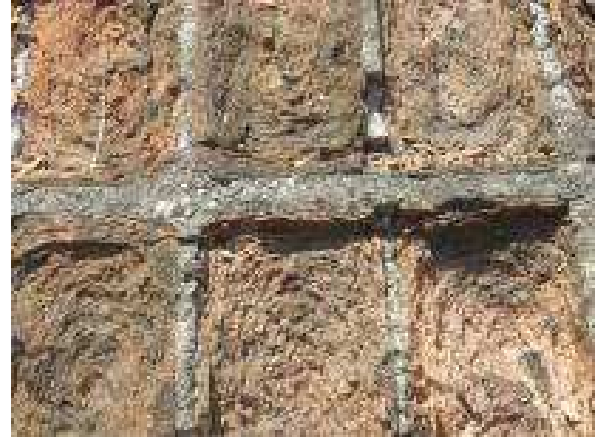

Fig. 3. Effects of corrosion with cement mortar stronger than ceramic material

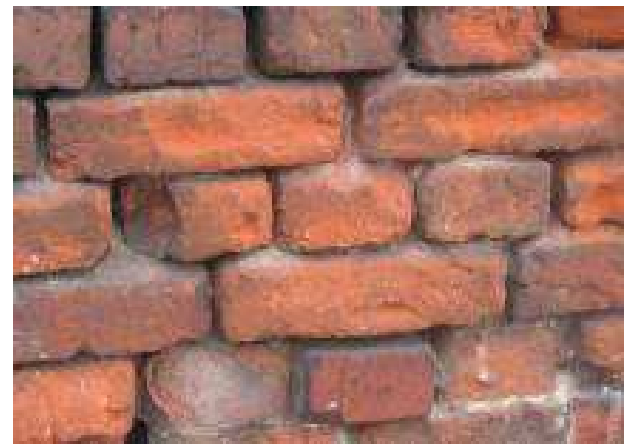

Fig. 4. The effects of corrosion in the wall on lime mortar of lower strength than brick

\section{CONTENT OF SALT IN THE WALLS}

The salinity level of the wall is, determined by laboratory, usually as a percentage, the salt content in the material. The survey allows for the classification of harmful salts load and is the basis in taking corrective actions.

According to the Austrian standard Ö-Norm B 3355 there are three groups of salinity. In the case of group I, one does not need the use of preventive or remedial construction materials. At the second level of salinity in some cases, corrective action should be taken. On the other hand, when the salinity in the tested object is on the third level, one should urgently apply corrective measures.

Table 1. Classification of salt load on the basis of the Austrian standard Ö-Norm B 3355 "Drying walls" [2]

\begin{tabular}{|c|c|c|c|}
\hline \multirow{2}{*}{ Anions } & \multicolumn{3}{|c|}{ Salinity in the percentage by mass } \\
\cline { 2 - 4 } & I & II & III \\
\hline Chloride & $<0,03$ & $0,03-0,10$ & $>0,10$ \\
\hline Nitrate & $<0,05$ & $0,05-0,15$ & $>0,15$ \\
\hline Sulphate & $<0,10$ & $0,10-0,25$ & $>0,25$ \\
\hline
\end{tabular}

WTA, which is the German Technical and Scientific Working Group of Monuments Protection and Restoration of the Old Building, which deals with the protection and maintenance of monuments and historical buildings, classifies salinity according to three degrees of building salt load: low, medium and high. 
Table 2. Levels of salts load according to the current instruction of WTA 2-9-04 / D "Systems of restoration plasters" [6]

\begin{tabular}{|c|c|c|c|}
\hline Salts & \multicolumn{3}{|c|}{ Content in \% (mass) } \\
\hline Level of load & low & medium & high \\
\hline Chlorides & $<0,2$ & $0,2-0,5$ & $>0,5$ \\
\hline Nitrates & $<0,1$ & $0,1-0,3$ & $>0,3$ \\
\hline Sulphates & $<0,5$ & $0,5-1,5$ & $>1,5$ \\
\hline
\end{tabular}

\section{RESULTS}

One analyzed the results of samples test from a dozen of houses located in close city centres. Total assay was performed on 231 samples. The paper will present test results of samples taken from several heights and depths within the same piece of wall and summaries from all facilities. Research conducted by the authors were based on chemical analyzes performed using the prepared chemical tests. Assays are made using titration and colorimetric methods.
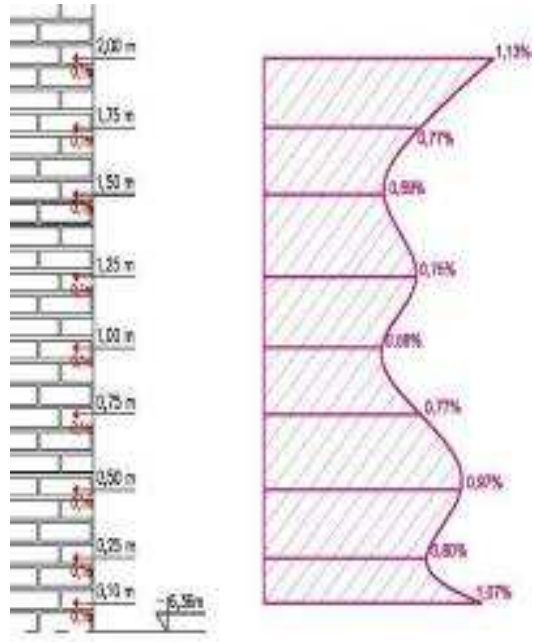

Fig. 5. Sulphates salinity distribution graph at the height of masonry basement walls at the samples collecting from depths of $0,1 \mathrm{~m}$

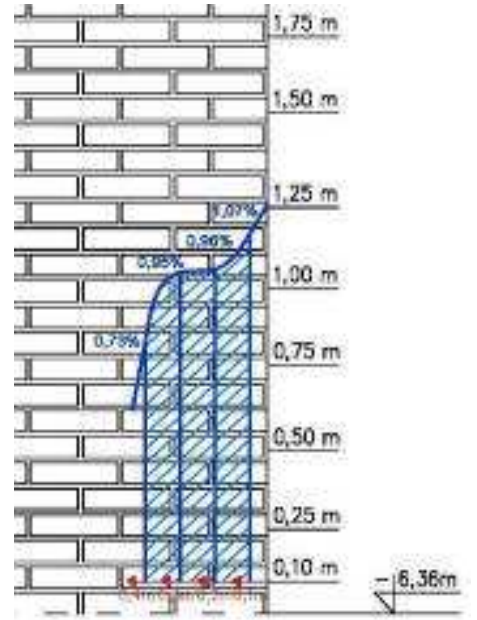

Fig. 6. Sulphates salinity distribution graph at a depth of $0.1 ; 0.2 ; 0.3$ and 0.4 $\mathrm{m}$ of basements masonry walls at the samples collecting from a height of $0,1 \mathrm{~m}$ 


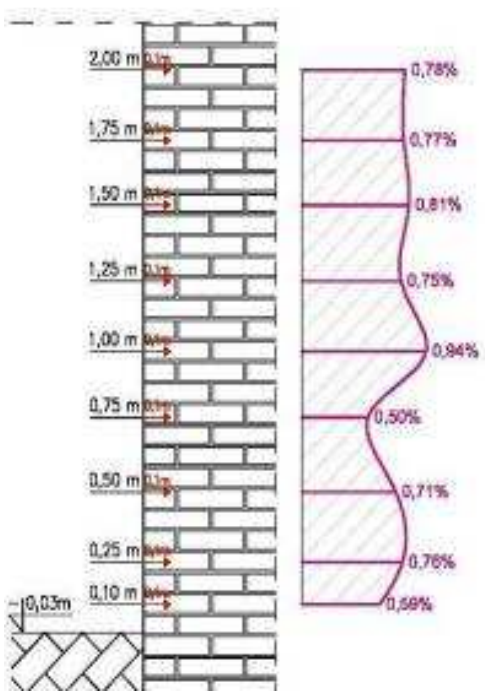

Fig. 7. Sulphates salinity distribution graph at a wall height of the structural wall from the outside at the samples collecting from the depth of $0,1 \mathrm{~m}$

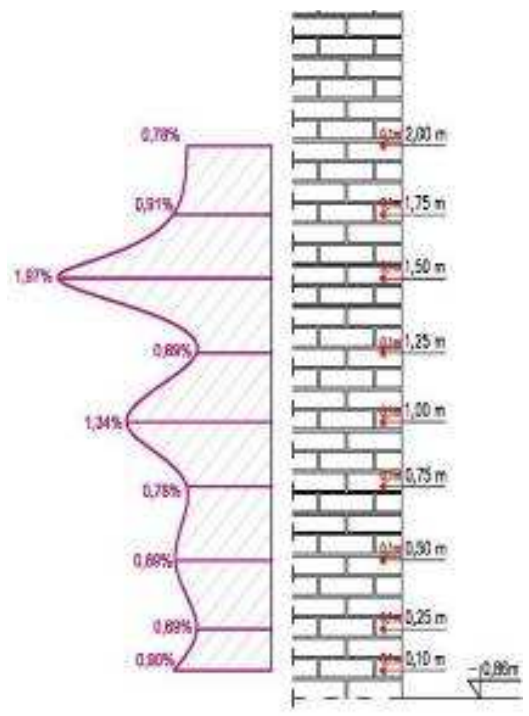

Fig. 9. Sulphates salinity distribution graph at a wall height of the structural wall on the inside at the samples collecting from depths of $0,1 \mathrm{~m}$

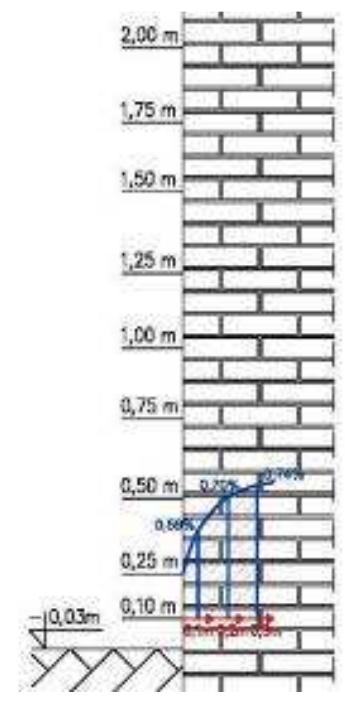

Fig. 8. Sulphates salinity distribution graph at a depth of $0.1 ; 0.2 ; 0.3$ masonry structural wall from the outside at the samples collecting from a height of $0,1 \mathrm{~m}$

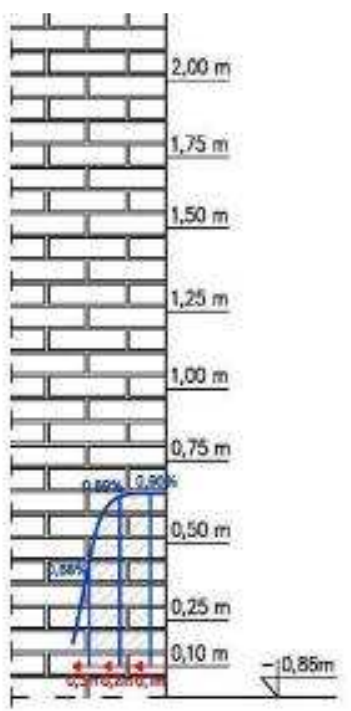

Fig. 10. Sulphates salinity distribution graph at a depth of $0.1 ; 0.2 ; 0.3$ masonry structural wall from the inside at the samples collecting from a height of $0,1 \mathrm{~m}$ 


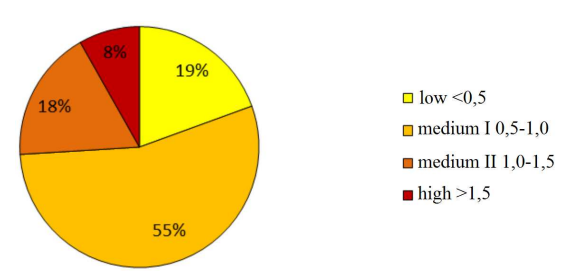

Fig. 11. The percentage of samples according to their level of sulphates load

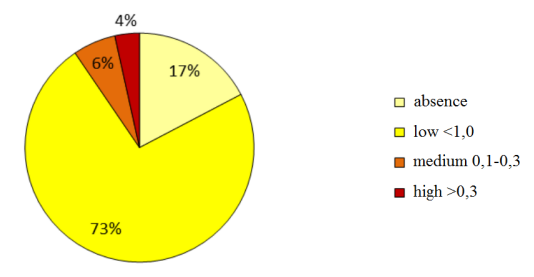

Fig. 13. The percentage of samples according to their level of chlorides load

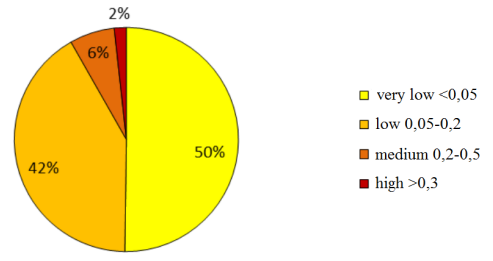

Fig. 12. The percentage of samples according to their level of nitrates load

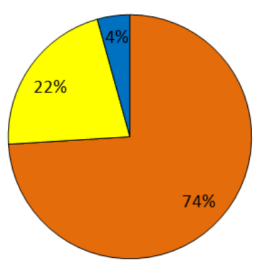

$\square$ acidic reaction $<6,5$ $\square$ neutral reaction $6,5-7,5$ a alkaline reaction $>7,5$

Fig. 14. The percentage of samples according to their $\mathrm{pH}$ value

\section{CONCLUSIONS}

Based on the analysis of test results of samples taken from the historic walls of ceramic bricks, it is found that:

- all test subjects are crucially affected by the building salts;

- in each of the analyzed objects is a problem of sulphates salinity, and the increased load affects as many as $81 \%$ of samples tested;

- salinity with chlorides and nitrates was less important, the increased level respectively occurred in $8 \%$ and $10 \%$ of the samples;

- level of building salts load largely depends on the height and the depth from which the samples were collected for analysis; in the case of sulphates:

- as expected at the height salinity distribution analysis, one found increased values in the level of maximum capillary water;

$\circ$ the presence of high salinity was found in all samples coming from greater wall depths;

- in the samples taken from the subsurface area, one revealed substantial differences in the results from both the interior and exterior;

- dominant $\mathrm{pH}$ value of the tested samples is acidic reaction (74\%) samples 


\section{REFERENCES}

1. Frössel F.: Osuszanie murów i renowacja piwnic, Warszawa, POLCEN Sp. z o.o. 2007.

2. Ö-Norm B 3355 „Osuszanie murów”.

3. Karaszkiewicza P.: Sole w obiektach budowlanych, Materiały budowlane nr $8 / 2002$.

4. Trochonowicz M.: Obiekty murowe $w$ ruinie. Wptyw czynników degradujacych na ich zachowanie, Trwata ruina II. Problemy utrzymania $i$ adaptacji. Ochrona, konserwacja i adaptacja zabytkowych murów, LublinWarszawa, LTN, Politechnika Lubelska, PKN ICOMOS, 2010.

5. Skibiński S.: Sole rozpuszczalne w wodzie, Renowacje nr 10/2000.

6. WTA 2-9-04/D Systemy tynków renowacyjnych.

\section{ANALIZA ROZKŁADU SOLI BUDOWLANYCH W MURACH Z CEGŁY CERAMICZNEJ KAMIENIC ŚRÓDMIEJSKICH}

\section{Streszczenie}

Celem analizy było przybliżenie problematyki związanej z korozyjnym działaniem soli budowlanych. Omówiono zagadnienia związane z dystrybucją soli w murze, źródłami zasolenia i typami uszkodzeń materiału murowego. Przedstawiono wyniki badań, które pozwoliły na wyznaczenie rozkładu zasolenia w murach w zależności od głębokości i wysokości próbkowania. Wyniki badań dotyczą próbek pobieranych z kilku wysokości i głębokości w obrębie tego samego fragmentu muru oraz próbek zbiorczych z wszystkich obiektów. Badania oparte zostały o analizy chemiczne wykonane przy użyciu gotowych testów chemicznych. Oznaczenia wykonywano metodami miareczkowania i kolorymetryczną.

Słowa kluczowe: sole rozpuszczalne, mury z cegły ceramicznej

Editor received the manuscript: $16.03 .2015 \mathrm{r}$. 
